\title{
KAMI-PMO TB (EDUKASI DAN PENDAMPINGAN PENGAWAS MENELAN OBAT TB) DALAM PENGENDALIAN MDR TB
}

\author{
Mareta Dea Rosaline ${ }^{1}$ dan Santi Herlina ${ }^{2}$ \\ ${ }^{1}$ Program Studi keperawatan, UPN Veteran Jakarta \\ maretarosaline@upnvj.ac.id \\ ${ }^{2}$ Program Studi Keperawatan, UPN Veteran Jakarta \\ santiherlina@upnvj.ac.id
}

\begin{abstract}
Tuberculosis control in Indonesia is still not optimal. The problem of MDR TB (Multidrug-Resistant Tuberculosis) is an obstacle to controlling $T B$ in Indonesia. MDR TB is caused by no response from TB germs to treatment isoniazid and rifampicin, anti-tuberculosis drugs. TB incidence rate in Serang district ranks second in Banten Province after Tangerang. The number of pulmonary TB cases is due to the lack of public knowledge and awareness about pulmonary $T B$ disease. To reduce the adverse effects of $M D R T B$ requires the involvement of cadres or family members who controlling drug ingestion (PMO). The form of activities carried out through the formation of cadres to care for TB through the KAMI-PMO TB (Education and Assistance for TB Medication Supervisors) in Desa Baros, Kabupaten Serang. The purpose is to increase the commitment, ability, and knowledge of cadres as coordinator of PMO (Drug Swallow Supervisor) to control MDR TB. The method of implementing activities is counseling, demonstrations, and assistance to cadres. The media used were PPT, WE-PMO TB Booklet, and educational videos. The result of the training was an increase in the ability of cadres in providing PMO counseling by $87 \%$. The Paired T-Test analysis results showed a p-value of 0.000 , which means that the training conducted affected cadres' knowledge of PMO TB. In conclusion, education and assistance to cadres have a good influence in increasing knowledge and abilities. The expected result is TB care cadres can provide aid and become the coordinator of TB PMO (Drug Ingestion Supervisor).
\end{abstract}

Keywords: Education, Tuberculosis, PMO, Multi Drug Resistant TB

\begin{abstract}
ABSTRAK
Pengendalian Tuberculosi di Indonesia masih belum optimal. Permasalahan MDR TB (Multidrug Resistant Tuberculosis) merupakan hambatan pengendalian TB di Indonesia. MDR TB disebabkan tidak ada respon kuman TB terhadap pengobatan isoniazid dan rifampizin yang merupakan obat anti tuberculosis. Angka kejadian TB di kabupaten Serang menempati urutan kedua di Provinsi Banten setelah Tangerang, dan banyaknya kasus TB Paru dikarenakan pengetahuan dan kesadaran masyarakat tentang penyakit TB Paru masih kurang. Untuk mengurangi dampak buruk MDR TB dibutuhkan keterlibatan peran serta kader peduli TB atau anggota keluarga yang berperan dalam pengawasan menelan obat (PMO). Bentuk kegiatan yang dilakukan sebagai bentuk pemberdayaan masyarakat melalui pembentukan kader peduli TB melalui KAMI-PMO TB (Edukasi dan Pendampinga Pengawas Menelan Obat TB) di Desa Baros Kabupaten Serang. Tujuan dari pengabdian masyarakat adalah meningkatkan komitmen, kemampuan dan pengetahuan kader sebagai koordinator PMO (Pengawas Menelan Obat) dalam upaya pengendalian MDR TB. Metode pelaksanaan kegiatan adalah penyuluhan, demontrasi, dan pendampingan kader. Media yang digunakan yaitu PPT, Booklet KAMI-PMO TB, dan video edukasi. Hasil dari kegiatan adalah meningkatnya kemampuan kader dalam memberikan penyuluhan PMO cukup tinggi sebesar 87\%. Hasil analisis uji Paired T- Test didapatkan nilai p value 0,000 yang artinya ada pengaruh pelatihan yang dilakukan terhadap pengetahuan kader tentang PMO TB. Kesimpulannya edukasi dan pendampingan kepada kader memiliki pengaruh yang baik dalam meningkatkan pengetahuan dan kemampuan, sehingga hasil yang diharapkan kader peduli TB dapat melakukan pendampingan pada pasien TB dan menjadi koordinator PMO (Pengawas Menelan Obat) TB dalam upaya pengendalian MDR TB.
\end{abstract}

Kata Kunci: Edukasi, Tuberculosis, PMO, MDR TB

\section{PENDAHULUAN}

Tuberkulosis (TB) adalah penyakit infeksi menular yang disebabkan oleh kuman mycobacterium tuberculosis (WHO, 2018). Tuberkulosis menyebar melalui udara ketika seseorang dengan infeksi TB aktif batuk, bersin, atau menyebarkan butiran ludah mereka melalui udara (Potter \& Perry, 2005). Potensi penyebaran TB sangatlah mudah dan tergolong cepat. TB dapat disembuhkan dengan 
regimen pengobatan yang baik. Jika seseorang tidak menerapkan regimen pengobatan dengan baik dapat menyebabkan kematian akibat TB (WHO, 2018). Pengobatan TB paru pada fase intensif, klien mendapat obat setiap hari dan perlu diawasi setiap hari untuk mencegah terjadinya resistensi obat (Akshata, 2018). Bila pengobatan pada fase ini dilakukan secara tepat maka klien TB paru menjadi tidak menular dalam kurun waktu 2 minggu, dan sebagian besar klien TB paru BTA (Bakteri Tahan Asam) positif menjadi BTA negatif dalam waktu 2 bulan, sehingga klien tidak mengalami drop out dan pengobatan ulang (Kemenkes, 2017). Tuberkulosis paru (TB) masih merupakan masalah di dunia. Organisasi kesehatan dunia (WHO) melaporkan pada tahun 2017 terdapat 9,6 juta kasus TB setiap tahunnya, dan tingkat kematian mencapai 1,5 juta kasus per tahun. Diantara 9,6 juta kasus TB tersebut didapatkan 1,1 juta kasus TB atau sekitar $12 \%$ yang juga mengalami HIV positif dengan tingkat kematian 320.000 orang, dan 480.000 kasus atau sekitar 5\% adalah TB Multi Drug Resisten (MDR- TB) dengan tingkat kematian 190.000 orang (WHO, 2018).

Indonesia merupakan negara dengan insiden tertinggi ke-2 di dunia setelah India dengan jumlah kasus baru TB sebanyak 420.994 kasus pada tahun 2017 (data Riskesdas per 17 Mei 2018). WHO menetapkan standar keberhasilan pengobatan sebesar 85\%. Angka keberhasilan pada tahun 2017 sebesar 87,8\% (data Riskesdas per 21 Mei 2018). Angka keberhasilan (succes rate) adalah jumlah semua kasus TBC yang sembuh dan pengobatan lengkap di antara semua kasus TBC yang diobati dan dilaporkan yang angka ini merupakan penjumlahan dari angka kesembuhan semua kasus dan angka pengobatan lengkap semua kasus. Penderita penyakit tuberkulosis (TB) di Kabupaten Serang terus bertambah. Angka kejadian TB di kabupaten Serang menempati urutan kedua di Provinsi Banten setelah Tangerang, dan banyaknya kasus TB Paru ini dikarenakan pengetahuan dan kesadaran masyarakat tentang penyakit TB Paru masih kurang (Dinkes Kabupaten Serang, 2018). Berdasarkan data dari Dinas Kesehatan (Dinkes) Kabupaten Serang, pada tahun 2018 penderita TB mencapai 1.476 kasus dan pada tahun 2018 meningkat menjadi 1616 kasus. Desa Baros merupakan desa dengan prevalensi TB Paru tertinggi yaitu sebanyak 47 kasus pada tahun 2017, dan meningkat pada tahun 2018 (Badan Pusat Statistik Kecamatan Baros, 2018). Tingginya angka kejadian TB di desa Baros disebabkan karena ketidakpatuhan pasien dalam menjalani pengobatan atau kesalahan dalam memberikan formulasi obat sehingga dapat menyebabkan TB MDR (Dinkes Kabupaten Serang, 2017). Hal itu disebabkan penyebaran virus yang begitu cepat melalui udara. Satu penderita bisa menularkan virus TB kepada 15 orang (Denkinger, 2013). Penderita TB harus mendapatkan pengobatan rutin selama enam hingga delapan bulan Jika pengobatan terputus, penderita akan mengalami multi-drugs resistant (MDR) atau kegagalan pengobatan (Behzadifar, 2015). Kondisi itu akan membuat pasien membutuhkan pengobatan lebih lama lagi (Kemenkes, 2018).

Secara umum dan mendasar beberapa permasalahan yang dihadapi oleh mitra yaitu kurangnya pemahaman PMO (Pengawas Menelan Obat) mengenai penyakit Tuberkulosis Paru, kurangnya pemahaman PMO (Pengawas Menelan Obat) mengenai peran dan tugas yang harus dijalankan sebagai seorang PMO (Pengawas Menelan Obat), Belum optimalnya pelatihan yang dilakukan oleh dinas terkait dalam upaya meningkatkan pengetahuan PMO (Pengawas Menelan Obat) tentang penyakit tuberculosis, belum optimalnya pelatihan yang dilakukan oleh dinas terkait dalam upaya meningkatkan pengetahuan PMO (Pengawas Menelan Obat) tentang peran dan tugas sebagai PMO (Pengawas Menelan Obat), dan kurangnya pendampingan yang dilaksanakan oleh tenaga kesehatan kepada PMO (Pengawas Menelan Obat) dalam rangka memantau pengawasan pemberian obat kepada penderita tuberculosis. Permasalahan "multi drug resisten " merupakan hambatan pengendalian TB di Indonesia. Multidrug Resistence disebabkan oleh tidak ada respon kuman TB terhadap pengobatan isoniazid dan rifampizin yang merupakan obat anti tuberculosis (Tiberi et al., 2019). Pasien TBC minimal mendapatkan pengobatan selama 6 bulan. Ketidakpatuhan pasien dalam menjalani pengobatan atau kesalahan dalam memberikan formulasi dapat menyebabkan TB MDR (WHO, 2018). 
WHO (World Health Organization) mengembangkan strategi pengendalian TB termasuk untuk di Indonesia yaitu dengan strategi TOSS (Temukan, Obati Sampai Sembuh). Fokus utama TOSS (Temukan, Obati Sampai Sembuh). adalah penemuan dan penyembuhan pasien TB. Salah satu dari komponen TOSS (Temukan, Obati Sampai Sembuh) adalah panduan OAT (Obat Anti Tuberkulosis) jangka pendek dengan pengawasan langsung (WHO, 2018). Untuk menjamin keteraturan pengobatan diperlukan seorang Pengawas Menelan Obat (PMO) (Kemenkes, 2017). Salah satu usaha untuk menjamin pasien tetap semangat menelan obat sampai sembuh adalah menyiapkan seseorang untuk mendampingi pasien TB, disebut PMO (Pengawas Menelan Obat). Tugas seorang PMO adalah: 1) Mengawasi pasien TB agar menelan obat secara teratur sampai selesai pengobatan, 2) Memberi dorongan kepada pasien agar mau berobat teratur, 3) Mengingatkan pasien untuk periksa ulang dahak pada waktu yang telah ditentukan, 4) Memberi penyuluhan pada anggota keluarga pasien TB yang mempunyai gejala-gejala mencurigakan TB untuk segera memeriksakan diri ke Unit Pelayanan Kesehatan.

Solusi yang ditawarkan adalah Tindakan pengendalian Multi Drug Resistant dan penularan TB yang dilakukan berupa "KAMI-PMO TB" (Edukasi dan Pendampingan Pengawas Menelan Obat TB) pada kader peduli TB. Kegiatan ini sejalan dengan strategi TOSS (Temukan, Obati Sampai Sembuh) yang dikembangkan di Indonesia yaitu komponen standarisasi pengobatan dengan pengawasan dan dukungan pasien. Indonesia mengembangkan strategi tersebut dalam program Pengawas Menelan Obat (PMO), suatu bentuk pengawasan terhadap kepatuhan meminum obat sesuai program kepada penderita TB. Pengawas Minum Obat yang memantau dan mengingatkan penderita TB paru untuk meminum obat secara teratur. PMO sangat penting untuk mendampingi penderita agar tercapai hasil pengobatan yang optimal (Kemenkes, 2017). Bentuk kegiatan yang dilakukan merupakan bentuk upaya promotif dan preventif ditujukan sebagai bentuk pemberdayaan dan kerja sama dengan masyarakat melalui pembentukan kelompok pendukung melalui “KAMI-PMO TB” di Desa Baros Kabupaten Serang. Manfaat dari pengabdian masyarakat ini adalah meningkatkan komitmen, kemampuan dan pengetahuan kader peduli TB dan keluarga pasien TB sebagai PMO (Pengawas Menelan Obat) dalam upaya pengendalian multidrug resisten tuberculosis

\section{METODE PELAKSANAAN PKM}

Kegiatan pengabdian ini adalah KAMI-PMO TB, yaitu edukasi dan pendampingan pengawas Menelan Obat TB) pada kader peduli TB yang dilaksanakan di Kampung Sumur Petey Desa Baros Kecamatan Baros Kabupaten Serang. Peserta kader kesehatan peduli TB sebanyak 23 orang. Metode yang digunakan dalam program pengabdian masyarakat ini berupa penyuluhan, demontrasi, dan pendampingan. Media yang digunakan yaitu PPT, Booklet KAMI-PMO TB , dan video edukasi PMO. Monitoring dan evaluasi diperoleh dari lembar presentasi atau lembar kehadiran peserta serta kemampuan kader untuk melakukan penyuluhan PMO TB. Kegiatan monitoring dilakukan dengan observasi langsung pada saat penyuluhan dan demontrasi dengan melihat interaksi peserta dengan pemateri penyuluhan dan keaktifan masyarakat dalam demontrasi. Evaluasi dilakukan dengan menilai peningkatan pengetahuan/demontrasi melalui evaluasi pre test dan post test terkait materi dan demontsrasi yang dilakukan. Data dikumpulkan dengan menggunakan kuisioner dalam pertanyaan untuk mengetahui pengetahuan peserta sebelum dan sesudah penyuluhan. Analisis data menggunakan uji Paired-Samples T Test.

\section{HASIL DAN PEMBAHASAN}

Hasil pengabdian ini didapatkan pada karakteristik responden berupa umur, jenis kelamin, dan pendidikan seperti tertera pada Tabel 1. 
Tabel 1.Disribusi Karakteristik Kader Kesehatan Berdasarkan Usia Tahun 2020 (n=23)

\begin{tabular}{llll}
\hline Variabel & Mean & SD & Min-Max \\
\hline Umur & 40,3 & 8,52 & $25-52$ \\
\hline
\end{tabular}

Berdasarkan Tabel 1 menunjukkan bahwa kader kesehatan di Desa Baros rata-rata berusia 40 tahun dengan usia. Termuda adalah 25 tahun, dan usia tertua adalah 52 tahun.

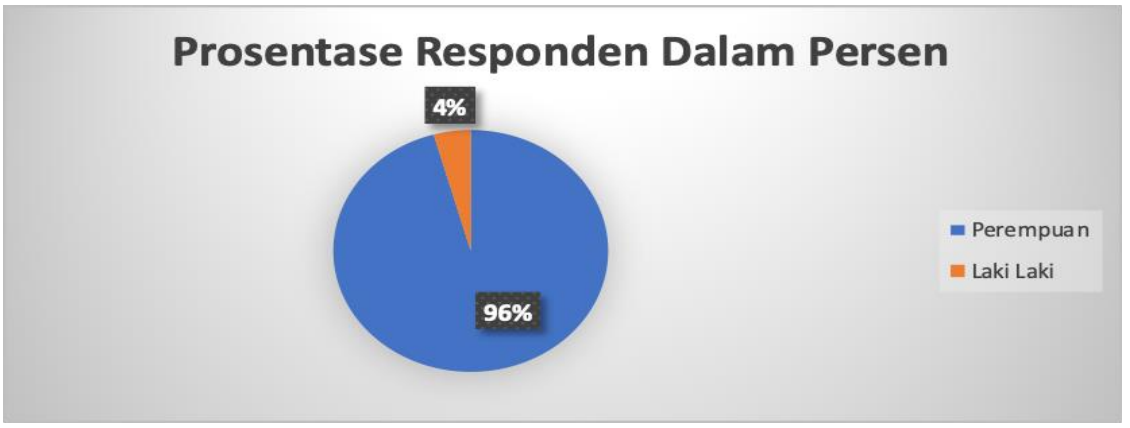

Gambar 1. Prosentase Kader Kesehatan Berdasarkan Jenis kelamin ( $\mathrm{n}=23)$

Berdasarkan Gambar 1 menunjukkan bahwa kader kesehatan di Desa Baros adalah perempuan.sebanyak 22 orang (96\%)

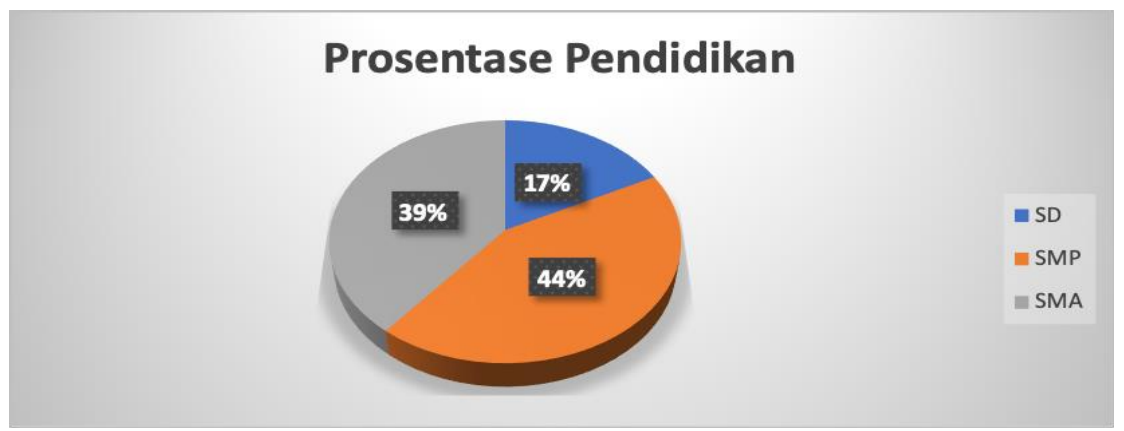

Gambar 2. Prosentase Kader Kesehatan Berdasarkan Pendidikan (n=23)

Berdasarkan Gambar 2 menunjukkan bahwa pendidikan kader kesehatan di Desa Baros terbanyak adalah SMP sebanyak 10 orang (44\%).

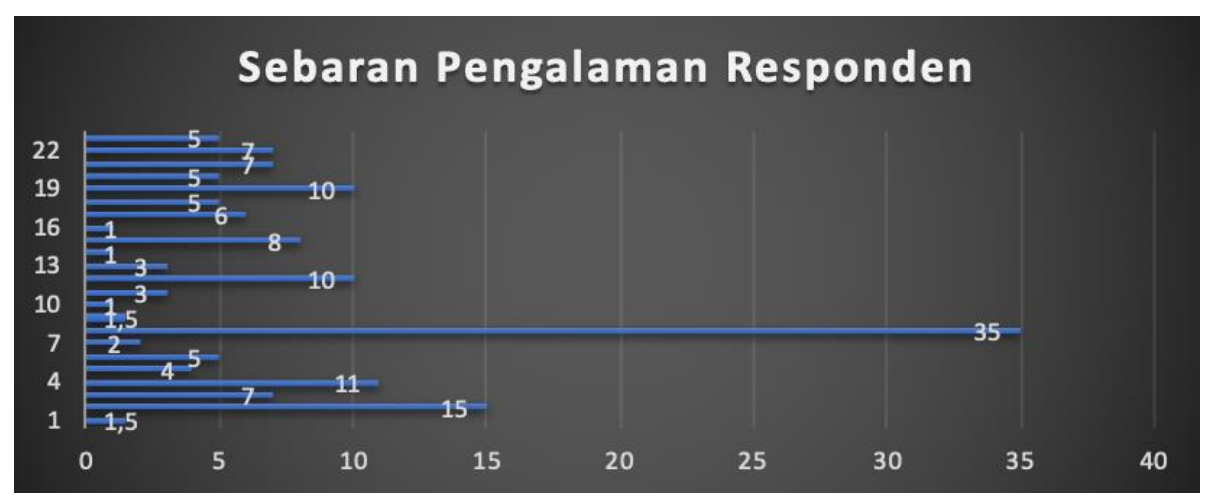

Gambar 3. Sebaran Pengalaman Menjadi kader (n=23) 
Berdasarkan Gambar 3 menunjukkan bahwa pengalaman kader menjadi kader kesehatan adalah paling lama 35 tahun sebanyak 1 orang.

Tahap Pelaksanaan yang dilakukan adalah :

1. Pembentukan Kader Peduli TB dan Komitmen Para Kader Peduli TB dengan Penyematan Pin KAMI-PMO TB sebagai Koordinasi PMO TB di Masyarakat.

Pembentukan kader peduli TB agar dapat melakukan tugas dengan baik untuk mengidentifikasi pasien TB dan membantu mendampingi proses pengobatan pasien hingga sembuh dan menjadi koordinator PMO TB yang ditunjukkan pada Gambar 4 dan Gambar 5 .

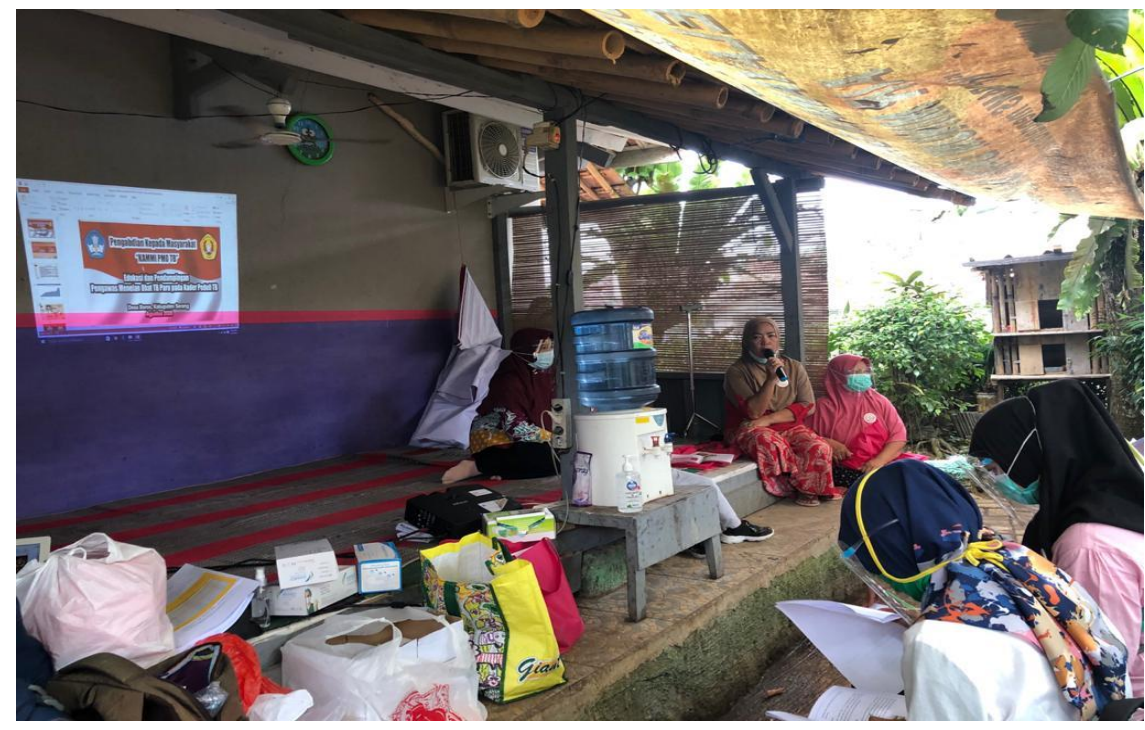

Gambar 4. Pembentukan kader Peduli TB oleh Ketua Kader Desa Baros

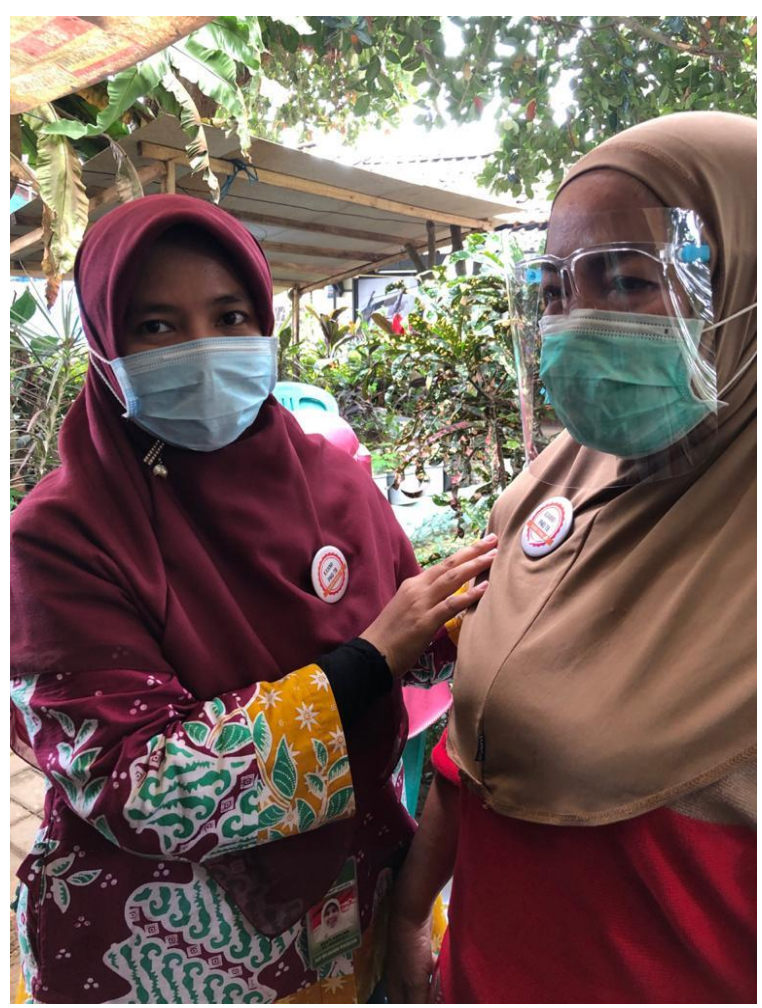

Gambar 5. Penyematan Pin KAMI-PMO TB sebagai komitmen kader 


\section{Pertemuan Tahap 1 ( Penguatan Materi Tuberkulosis)}

Pelatihan "KAMI-PMO TB" (Edukasi dan Pendampingan Pengawas Menelan Obat TB) pada kader peduli TB mengenai penyakit Tuberkulosis Paru yang meliputi pengertian, epidemiologi, tanda gejala, penularan, jenis pemeriksaan TB, pengelompokan pasien TB, pengobatan, pencegahan penularan TB yang ditunjukkan pada Gambar 6.

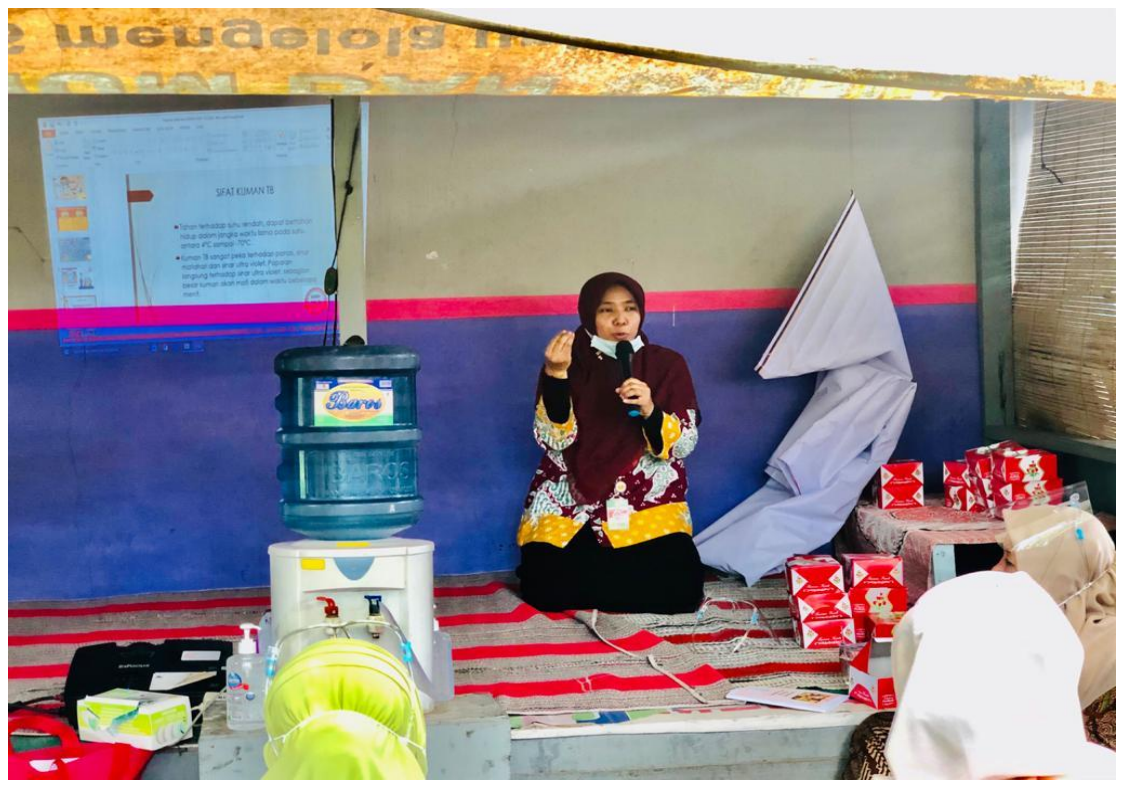

Gambar 6. Penyuluhan kepada peserta kader

\section{Pertemuan Tahap 2 (Pemberdayaan Masyarakat dalam Penanggulangan TB)}

Pelatihan "KAMI-PMO TB" (Edukasi dan Pendampingan Pengawas Menelan Obat TB) mengenai pemberdayaan masyarakat dalam pengertian kader TB, peran dan manfaat menjadi kader TB, peran kader dalam penemuan dan pendampingan kasus TB, optimalisasi peran dan tugas PMO dan penjelasan tentang fungsi TB Kit yang berisi berisi kotak obat selama 7 hari, medicine kit, masker, dan booklet untuk pasien TB Paru pada pasien TB Paru, dan cara petuntuk pengisian kartu kontrol PMO. Pengawasan pengobatan pasie TB BTA positif baru sangat penting untuk memastikan bahwa pengobatan berlangsung dengan baik dan berhasil sampai sembuh. Untuk itu seorang PMO yang terlatih dan memiliki keterampilan dalam pengawasan pengobatan pasien TB, merupakan suatu kebutuhan program penanggulangan TB yang paling penting dan mendasar. Keberhasilan memutuskan rantai penularan TB dan pengendalian MDR TB bergantung pada suksesnya PMO melakukan pengawasan pengobatan hingga dinyatakan sembuh oleh tenaga kesehatan. Untuk mendukung keberhasilan program penanggulangan TB, dibutuhkan PMO yang secara sukarela, mau dan mampu menjadi Pengawas Menelan Obat (PMO). Tujuannya adalah 1)Untuk memberikan pemahaman tentang tugas dan fungsi PMO, 2)Untuk melatih para PMO agar terampil dalam berkomunikasi dengan pasien TB dalam proses pemantauan meminum obat, 3)Untuk melatih para PMO agar mampu mengawasi pengobatan pasien TB hingga dinyakan sembuh oleh tenaga kesehatan, 4)Untuk memberikan keterampilan bagi para PMO agar mampu mengontrol pengobatan pasien TB melalui pencatatan di kartu kontrol pada Gambar 7 dan Gambar 8. 


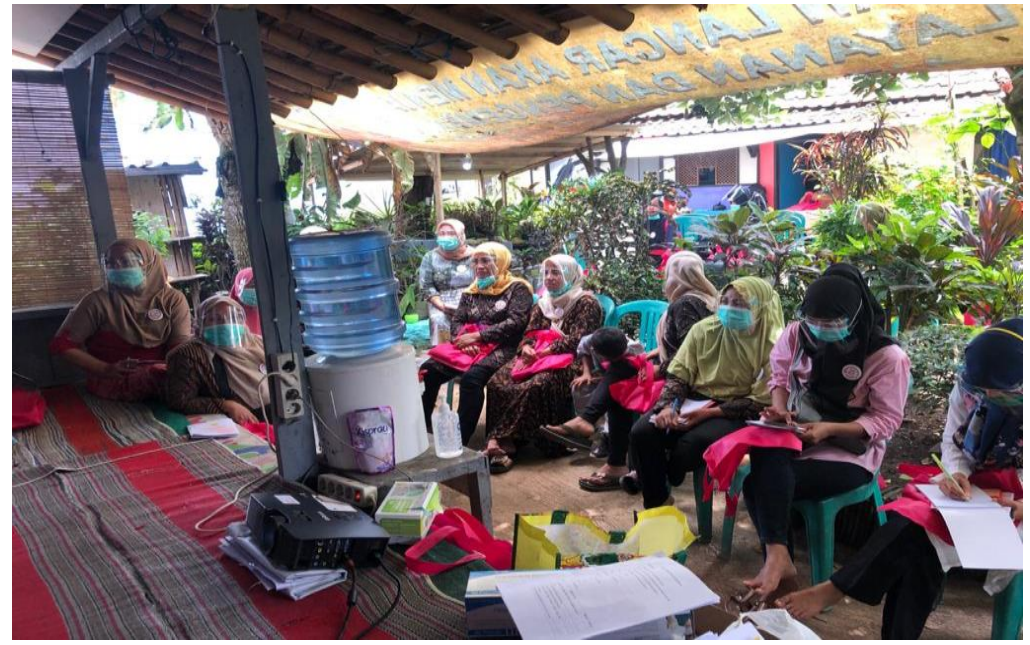

Gambar 7. Penyuluhan kepada peserta kader

\section{Pertemuan Tahap 3 (Pendampingan pada Kader dan anggota keluarga sebagai PMO} (Pengawas Menelan Obat)

Edukasi terhadap pasien TB, dan pemantauan kemajuan pengobatan pasien, melatih kembali kader agar terampil menyuluh di komunitas dan melatih kembali kader untuk terampil melakukan pencatatan dan pelaporan kasus TB. Setiap peserta dinilai kemampuannya dalam melakukan pendampingan yang ditunjukkan pada gambar 8 .

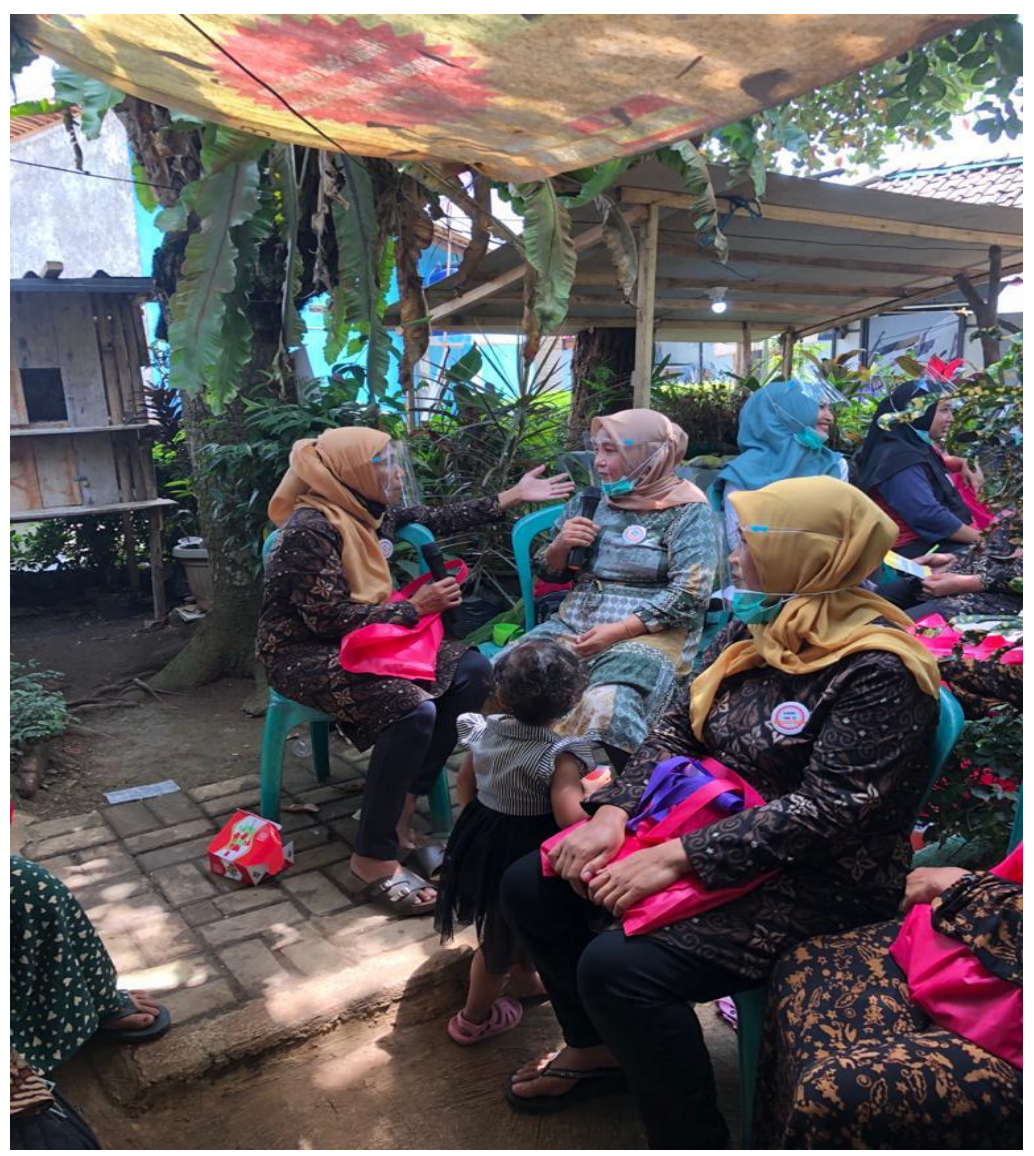

Gambar 8. Suasana Roleplay dan Diskusi Peserta Terkait Pendampingan KAMI-PMO TB 


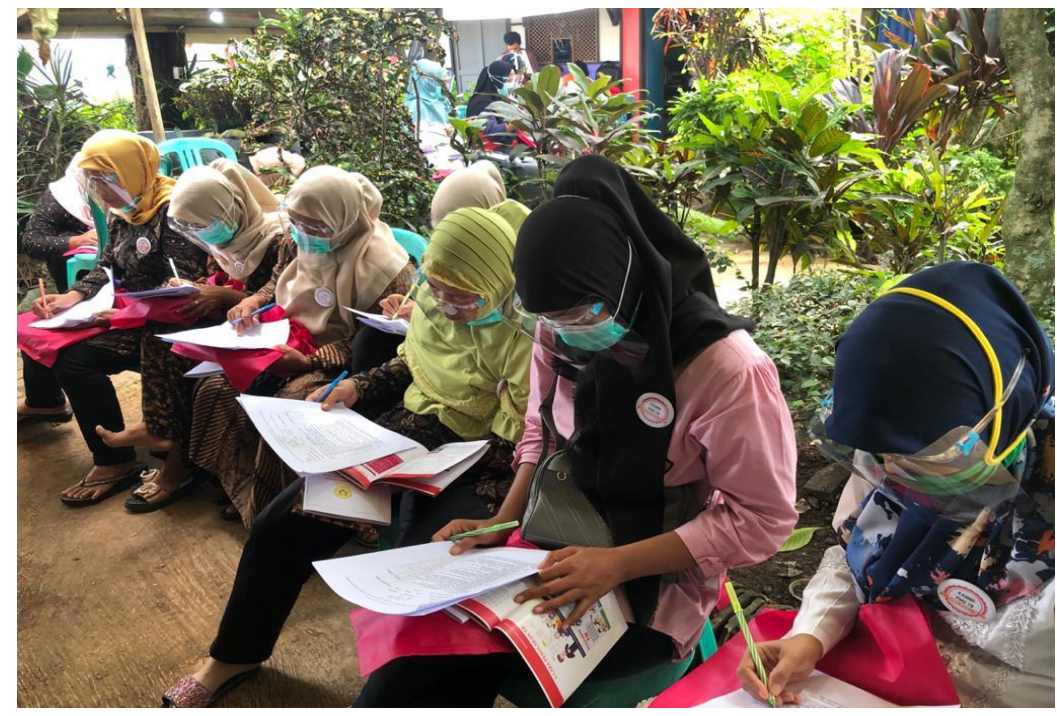

Gambar 9. Suasana Post tes

\section{Tahap Monitoring dan Evaluasi}

Kader Kesehatan dan Anggota Keluarga TB (KAMI-PMO TB) dikumpulkan kembali untuk mereview hasil pelatihan dan memonitor kegiatan kader setiap tiga bulan sekali dalam pelaksanaan KAMI-PMO TB Setelah diberikan pelatihan KAMI-PMO kepada kader dapat terlihat peningkatan pengetahuan kader kesehatan dan kemampuan dalam memberikan penyuluhan TB kepada masyarakat. Hal tersebut dapat dilihat pada tabel 2 dan 3. Pada tabel 2 terlihat bahwa kemampuan kader dalam memberikan penyuluhan PMO cukup tinggi sebesar $87 \%$.

Tabel 2. Distribusi Kemampuan Kader Kesehatan ( $\mathrm{n}=23)$

\begin{tabular}{lll}
\hline Variabel & $\mathbf{n}$ & \% \\
\hline Kemampuan skill & & 87 \\
\hline a.Mampu & 20 & 13 \\
\hline b.Kurang mampu & 3 & 100,0 \\
\hline Total & 23 & \\
\hline
\end{tabular}

Tabel 3. Pengetahuan kader sebelum dan sesudah dilakukan penyuluhan adalah sebagai berikut :

\begin{tabular}{lllll}
\hline Variabel & n & Mean & Standar Deviasi \\
\hline $\begin{array}{l}\text { Pengetahuan } \\
\text { pelatihan }\end{array}$ & sebelum & 23 & 6.660 & 1.190 \\
\hline $\begin{array}{l}\text { Pengetahuan } \\
\text { pelatihan }\end{array}$ & setelah & 23 & 11.700 & 1.436 \\
\hline
\end{tabular}

Adapun hasil analisis pengaruh pelatihan KAMI-PMO TB (Edukasi dan Pendampingan Pengawas Menelan Obat TB) terhadap pengetahuan kader di Desa Baros adalah sebagai berikut:

Tabel 4. Pengaruh Pelatihan KAMI-PMO TB terhadap pengetahuan kader

\begin{tabular}{lccllll}
\hline Variabel & $\mathbf{n}$ & Mean & Standar Deviasi & $\begin{array}{l}\text { Standard } \\
\text { Mean }\end{array}$ & Error & P Value \\
\hline $\begin{array}{l}\text { Pengetahuan sebelum } \\
\text { dan sesudah pelatihan }\end{array}$ & 23 & -5.040 & 1.332 & 0.298 & 0,000 \\
\hline
\end{tabular}


Berdasarkan tabel 4 menunjukkan bahwa dari 23 orang kader rata-rata pengetahuan sebelum dan sesudah penyuluhan adalah -5.5040 dengan standar deviasi 1.332, standar error mean 0.298 dengan nilai $\mathrm{P}$ Value 0,000 lebih kecil dari $0,05 \alpha$ yang artinya ada pengaruh pelatihan terhadap pengetahuan kader di Desa Baros.

Pelatihan yang disampaikan dapat meningkatkan pengetahuan peserta dibuktikan dengan respon yang cepat dalam menjawab semua pertanyaan yang diberikan dengan benar serta dapat langsung mempraktekkan kemampuan peserta dalam melakukan edukasi ke mayarakat terutama keluarga pasien TB terkait PMO TB. Sebagai tolak ukur peningkatan pengetahuan kader adalah mereka dapat mempraktikkan kembali terkait edukasi kepada masyarakat. Selain itu, para kader bisa mempraktekkan langsung dengan menggunakan media video edukasi. Berdasarkan evaluasi pelaksanaan kegiatan, dapat di identifikasi faktor pendukung dan penghambat dari kegitan ini sehingga dapat berjalan baik dan lancar antara lain mendapat dukungan dari kepala desa Baros, ketua RW, ketua RT, dan ketua kader yang bersedia diajak bekerja sama dan mendukung program pengabdian masyarakat. Serta antusiasme dari peserta kader peduli TB dalam pengabdian masyarakat ini. Sedangkan faktor penghambat dalam pengabdian ini adalah kurang luasnya tempat untuk melakukan penyuluhan karena berpedoman pada protokol COVID-19 yaitu social distancing, jarak minimal 1-2 meter. Hambatan bisa diatasi dengan kursi peserta minimal jarak 1 meter dan peserta tetap memakai face shield disamping menggunakan masker. Hasil yang diharapkan pada tahap ini kader kesehatan peduli TB dapat melakukan pendampingan pada pasien TB dan menjadi koordinator PMO (Pengawas Menelan Obat) TB dalam upaya pengendalian multidrug resisten tuberculosis.

\section{KESIMPULAN}

Pengabdian Kepada Masyarakat tentang Program Kemitraan Masyarakat telah dilakukan dengan tujuan untuk meningkatkan komitmen, kemampuan dan pengetahuan kader sebagai koordinator PMO (Pengawas Menelan Obat) dalam upaya pengendalian MDR TB.Adapun kegiatan yang dilakukan adalah "KAMI-PMO TB" (Edukasi dan Pendampingan Pengawas Menelan Obat TB) pada kader kesehatan peduli TB di Desa Baros Kecamatan Baros Kabupaten Serang. Edukasi dan Pendampingan kepada kader memiliki pengaruh yang baik dalam meningkatkan pengetahuan dan kemampuan, sehingga diharapkan dapat Hasil yang diharapkan pada tahap ini kader kesehatan peduli TB dapat melakukan pendampingan pada pasien TB dan menjadi koordinator PMO (Pengawas Menelan Obat) TB dalam upaya pengendalian multidrug resisten tuberculosis.

\section{UCAPAN TERIMA KASIH}

Ucapan terimakasih penulis sampaikan kepada UPN Veteran Jakarta yang telah memberikan dana hibah untuk melaksanaan kegiatan Pengabdian Masyarakat. Secara khusus ucapan terima kasih penulis sampaikan kepada 1)Rektor UPN Veteran Jakarta, 2) Ketua Lembaga Penelitian dan Pengabdian Masyarakat (LPPM) UPN Veteran Jakarta 3) Dekan Fikes UPN Veteran Jakarta, 4)Dinas Kesehatan Kabupaten Serang , 5)Kepala Desa Baros, 6)Para Kader di Desa Baros.

\section{REFERENSI}

Akshata, JS., Chakrabarthy, Anushree (2018). Management of multidrug resistant tuberculosis (MDR-TB) - Monitoring is the key to successful outcome. Egyptian Journal of Chest Diseases and Tuberculosis. 14 (1). 2016-2029. http://dx.doi.org/10.1016/j.ejcdt.2015.12.018

Badan Pusat Statistik. Statistik daerah Kecamatan Baros Tahun 2018. BPS Kecamatan Baros : Kabupaten Serang. Banten 
Behzadifar, M. Mirzaei, M. Keshavarzi, A. et al. (2015).Patients Experience of Tuberculosis Treatment Using Directly Observed Treatment Short-Course (DOTS) a Quality Study. Iran: Iran Red Crescent Med. J. 17(4). 2015.202 doi: 10.5812/ircmj

Denkinger CM., Kik SV., Pai M. (2013). Robust, reliable and resilient: designing molecular tuberculosis tests for microscopy centers in developing countries. Expert Rev. Mol. Diagn. 13(8), 763-767.

Dodor, E. (2012). The Feelings and Experience of Patients with Tuberculosis in The SekondiTakoradi Metropolitan District Implications for TB ControlEfforts. Ghana Medical Journal 46(4). 863-867.

Dinkes, Kabupaten Serang. (2017). Profil Kesehatan Kabupaten Serang Tahun 2017: Dinkes Kabupaten Serang

Himawan, A., Hadisaputro, S. dan Suprihati (2015) 'Berbagai Faktor Risiko Kejadian TB Paru Drop Out (Studi Kasus di Kabupaten Jepara dan Pati', Jurnal Kesehatan Masyarakat Indonesia, 2(1), pp. 57-63

Kementerian Kesehatan RI. (2016). Peraturan Menteri Kesehatan Nomor 67 Tahun 2016 tentang Penanggulangan Tuberkulosis, Jakarta. Kemenkes RI

Kementerian Kesehatan RI. (2017). Rencana aksi nasional Manajemen penangggulangan TB resisten obat di Indonesia 2016-2021. Kementerian Kesehatan RI: Jakarta.

Kemenkes, RI. (2017). Data dan Informasi Profil Kesehatan Indonesia 2016. Jakarta. Kemenkes RI

Kemenkes RI. (2018) Data dan Informasi Profil Kesehatan Indonesia 2017. Jakarta. Kemenkes RI

Kementerian Kesehatan Republik Indonesia. (2018). Info Datin: Tuberkulosis.

Natalya, W. dan Anwar, K. (2013) 'Perbedaan Kepatuhan Berobat Pada Penderita TB Paru yang Didampingi PMO dan Tidak Didampingi PMO di Wilayah Puskesmas Kabupaten Boyolali'.

Prawulandari, A. (2018) Pengalaman Pasien Multi Drug Resistant Tuberculosis ( Tb-Mdr ) Dalam Keberhasilan Pengobatan Di Wilayah Kota Semarang. Universitas Muhammadiyah Semarang.

Tiberi, Simon.,Emanuele, Pontali.,Marina,Tadolini., (2019). Challenging MDR-TB clinical problems, The case for a new Global TB Consilium supporting the compassionate use of new anti TB drugs. International Journal of Infectious Diseases. 50(2) 120-255. https://doi.org/10.1016/j.ijid.2019.01.040

UnitAid. 2017. TB Diagnostics Market in Select High-Burden Countries: Current Market and Future Opportunities for Novel Diagnostics. Unitaid: Vernier.

WHO, 2018. Global Tuberculosis Report 2018, Jenewa

WHO (2018).What is multidrug-resistant tuberculosis (MDR-TB) and how do we control it? http://www.who.int/features/qa/7 